\title{
A Comparative Analysis of Corporate Social Responsibility Activities of Companies in Banking Industry: An Application From Turkey
}

\author{
Bankacılık Sektöründeki Şirketlerin Kurumsal Sosyal Sorumluluk \\ Faaliyetlerinin Karşılaştırmalı Analizi: Türkiye Uygulaması \\ Utku DEMIRCI*
}

\begin{abstract}
The main purpose of this study is to investigate CSR activities of national, foreign and private banks listed in Borsa İstanbul (BIST) 30 Index in Turkey and reveal the differences between these banks in terms of the fulfilment of their social responsibilities. Within this scope; the concept of CSR, CSR definitions, the main reasons of CSR activities and four dimensions of CSR constitute the conceptual framework of the study. On the other hand; shareholder theory, stakeholder theory and institutional theory establish the theoretical framework of this study. In parallel with the study purpose, CSR practises of three different banks listed in BIST 30 Index as of the second quarter of year 2016 were analyzed. The relevant data were acquired from archival sources such as corporate governance compliance reports, annual sustainability reports and official company websites. The qualitative research was considered to be useful method to clarify the differences in social responsibility practises. For this reason, content analysis as a qualitative research method was used in order to investigate CSR activities of banks. Research findings reveal that there are not significant differences between Isbank (private bank) and VakıfBank (national bank) with regard to the fulfilment of their social responsibilities. On the other side, Garanti Bank (foreign bank) implements more CSR practises in comparison with other banks. This dissimilarity is also observed among CSR headings. All in all, a great majority of CSR activities are carried out about environmental conservation and stakeholders.
\end{abstract}

Key Words: Corporate social responsibility, banks, Borsa İstanbul, Turkey

Öz

Bu çalışmanın temel amacı, Borsa İstanbul (BİST) 30 Endeksi’nde işlem gören bankaların kurumsal sosyal sorumluluk faaliyetlerini araştırmak ve sosyal sorumluluklarını yerine getirme hususunda aralarındaki farklılıkları ortaya koymaktır. Bu kapsamda; KSS kavramı, KSS tanımları, KSS faaliyetlerinin başlıca nedenleri ve KSS'nin dört boyutu çalışmanın kavramsal çerçevesini teşkil etmektedir. Diğer taraftan; hissedar kuramı, paydaş kuramı ve kuramsal kuram ise çalışmanın teorik altyapısını oluşturmaktadır. Çalışmanın amacı doğrultusunda, 2016 yılının ikinci çeyreğinde BIST 30 Endeksi'ndeki üç farklı bankanın KSS faaliyetleri incelenmiştir. İlgili veri şirketlerin; kurumsal yönetim uyum raporları, yıllık sürdürülebilirlik raporları ve resmi internet siteleri gibi arşivsel kaynaklardan elde edilmiştir. Sosyal sorumluluk uygulamalarındaki farklılıkları açıklığa kavuşturmak için nitel araştırma metodunun uygulanması düşünülmüştür. $\mathrm{Bu}$ nedenle, bankaların kurumsal sosyal sorumluluk uygulamalarındaki farklılıkları araştırmak amacıyla nitel araştırma yöntemlerinden içerik analizi kullanılmıştır. Araştırma sonuçları, sosyal sorumlukların yerine getirilmesi bakımından İş Bankası (özel banka) ile Vakıfbank (kamu bankası) arasında önemli bir fark olmadığını göstermiştir. Öte yandan, bu bankalara nazaran Garanti Bankası (yabancı banka) daha fazla KSS uygulaması yürütmektedir. Bu farklılık, KSS başlıkları arasında da gözlemlenmiştir. Genel olarak değerlendirildiğinde, KSS faaliyetlerinin büyük çoğunluğunun çevre koruma ve paydaşlar hakkında gerçekleştirildiği görülmüştür.

Anahtar Kelimeler: Kurumsal sosyal sorumluluk, bankalar, Borsa İstanbul, Türkiye

\section{Introduction}

In the past fifty years, the notion of corporate social responsibility has been very popular both in business community and the academic field. Non-governmental organizations, governments, business world and scholars strive for promoting CSR. In recent years, many actors have been studying on the notion of CSR. Scientists address the concept in terms of its different aspects. Businesses incorporate CSR into their strategic activities. Governments make a law to promote and regulate activities of companies and non-governmental organizations take initiatives.

\footnotetext{
Arş. Gör., Muğla Sitkı Koçman Üniversitesi, İktisadi ve İdari Bilimler Fakültesi, İşletme Bölümü, utkudemirci@mu.edu.tr
}

Demirci, U.(2018). A Comparative Analysis of Corporate Social Responsibility Activities of Companies in Banking Industry: An Application From Turkey, Gaziantep University Journal of Social Sciences, 17(4), 14741490, Submission Date: 07-02-2018, Acceptance Date: 27-09-2018.

Araştırma Makalesi. 
Throughout history, companies were seen as only profit-oriented organisations. The main purpose of companies is to satisfy their owners by gaining high profit. Therefore, employee satisfaction and public welfare stayed in the background. In today's globalized world, companies are described economical and technical organizations. They are also defined as social corporates (Gülmez, 2011). Companies require restructure their organizational structure and identity inasmuch as consumers' needs and expectations change quickly. At the present time, not only consumers make decision according to price, quality or warranty while buy products, but they also investigate companies whether doing for benefit of society. For this reason, many companies attach particular importance to CSR acitivities in today's business world.

Many scholars debated and studied CSR activities of businesses in terms of different aspects in the academic field. Regarding this issue, the notion of CSR has been introduced by Bowen (1953) in his book which is "Social Responsibilities of the Businessman" as the starting point of the literature on social responsibility (Carroll, 1979). After this study; Drucker (1954), Davis (1960), McGuire (1963), McWilliams and Siegel (2001), Lee (2008) made contribution to the literature by giving different definitions about CSR. Nevertheless, scholars have not came together on common definition of CSR.

On the other side, some researchers suggest various CSR models in order to clarify the concept (Davis, 1976; Carroll, 1979; Wood, 1991). In addition to this, related concepts like business ethics, social responsiveness, social policy, corporate citizenship, corporate social performance were discussed in the academia (Carroll, 1999). At the beginning of the 1990s, the concept of globalization and its effects argued within business world. In this context, several relevant institutions such as Global Reporting Initiative (GRI), United Nations Global Compact (UNGC), Organisation for Economic Cooperation and Development (OECD) Guidelines for Multinational Enterprises arised and a number of standards like ISO 14001 (Environmental Management System Standard), SA8000 (Social Accountability Standard) and AA1000 (Accountability Ability Standard) were emerged so as to encourage sustainability and accountability (Matten \& Moon, 2008). After 2000s, CSR studies were shaped around leaders and social changes (Yamak, 2007).

This study is based on the topic: a comparative analysis of corporate social responsibility activities of companies in banking industry: an application from Turkey. Thus, the main research question of the present study is that "What are the differences between national banks, foreign banks and private banks in Turkey in terms of the fulfilment of their social responsibilities?" Majority of businesses carry on their activities in banking industry (Borsa İstanbul, 2016). For this reason, CSR practises of banks were investigated and compared in the study.

Regarding banking industry; three of those are private banks (Akbank T.A.S., T. Is Bankasi A.S. and Yapi ve Kredi Bankasi A.S.), two of these are national banks (T. Halk Bankasi A.S. and Türkiye Vakiflar Bankasi T.A.O.) and there is one foreign bank (T. Garanti Bankasi A.S.) in BIST 30 Index. At this point, one private bank (T. Is Bankasi A.S.), one national bank (Türkiye Vakiflar Bankasi T.A.O.) and one foreign bank (T. Garanti Bankasi A.S.) were selected among six banks in order to compare their social responsibility practises.

The reason why choosing T. Is Bankasi A.S., Türkiye Vakiflar Bankasi T.A.O. and T. Garanti Bankasi A.S. as a sample is the availability of sufficient data concerning CSR activities of these banks. Furthermore, except for banks' voluntary disclosures of their CSR activities, the obligation to publish corporate governance compliance reports for the listed companies in BIST 30 Index increases the availability of archival data of T. Is Bankasi A.S., Türkiye Vakiflar 
Bankasi T.A.O. and T. Garanti Bankasi A.S. Within this scope, CSR activities of these three banks listed will be analyzed so as to clarify this issue.

\section{Literature Review}

In today's business world, CSR plays a significant role in the success of companies. Therefore, this notion and its importance must be fairly understand by managers and companies. Literature review addresses the notion of CSR as conceptual and theoretical framework from different academic sources and historical backgrounds.

\section{Conceptual Framework}

CSR will be examined conceptually in this part of the study. The notion will be described and the main reasons of CSR activities such as economic factors, political factors and social factors will be explained in order to shed light on the concept. According to Carroll (1979), CSR is composed of four basic dimensions which are made up economic, legal, ethical and philanthropic responsibilities. These dimensions will be investigated in depth in the final part of conceptual framework. The main aim of this chapter is to understand the importance of CSR and clarify CSR activities of companies in business world through giving relevant information.

\section{The concept of CSR}

The concept of CSR is not a new phenomenon. For many years, CSR has been discussing in the literature. In historic process, companies were seen as only profit-oriented organisations. The main purpose of companies was to satisfy their owners by gaining high profit. Thus, employee satisfaction and public welfare were disregarded in the business world and academia (Gülmez, 2011). Nowadays, not only companies are economical and technical organizations but also they are defined social organizations who have social responsibilities and aims. Modern businesses carry on their activities under the influence of various social groups within complex environment. While companies are affected by this complex environment, they also influence their environment. At this point, companies bear responsibility towards all segments of society (Erden, 2011).

Regarding this issue, Erden (2011) states that CSR is continuation of the activities without detriment to company's stakeholders (e.g. shareholders, employees, government, customers, suppliers, investors, society, etc.) interests. In other words, the notion of CSR is explained as companies follow a strategy, which meets all interest groups' expectations, when they try to achieve its objectives. Hence, companies use their sources so as to raise public welfare level (Erden, 2011).

\section{CSR definitions}

Concerning the definitions of CSR, academia offers a number of viewpoints. In the academic literature, CSR is defined for the first time by Bowen (1953) in his book which is "Social Responsibilities of the Businessman". From this date on, CSR has been examined in terms of different perspectives. Bowen (1953) asserts business people must deal with social responsibility activities which are consonant with social value and social utility. However, Friedman (1970) emphasises that social responsibilities of businessman is only to make a profit.

According to Davis (1973), companies should deal with social activities beyond economic, technical and legal obligations. Similarly, Carroll (1979) indicates that economic, legal, ethical and philanthropic responsibilities of companies must be determined fairly as companies are accountable to the public. In this concept, CSR is described as an expectation of the public from economic, legal, ethical and philanthropic responsibilities of company within a fixed time (Carroll, 1979). 
On the other side, Basu and Palazzo (2008) point out the effect of company's corporate structure on CSR activities rather than traditional CSR approaches based on external factors. Because sense-making of company directly influences the relationship with stakeholders. For this reason, corporate structure of company must be examined in depth to understand better the process of sense-making and company's relationships with their stakeholders (Basu \& Palazzo, 2008).

As is seen from academic literature, CSR definitions of scholars are inconsistent. Though there is not a consensus on the definition of the notion, CSR refers to be ethical and liable for all stakeholders within internal and external environment of company. It also means protection the interests of all groups which are impressed directly or indirectly by company's activities (Gülmez, 2011).

\section{The main reasons of $\mathrm{CSR}$ activities}

Economic Factors: Liberalism, which emerged immediately before 1900s in the Industrial Revolution, supports freedom to operate, extinction of customs and free competition. In addition, it goes against intervention of the state in terms of implementation of economic policies. The Great Depression which started in 1929 and lasted until the late 1930s has affected largely business life and economic order of governments. Role of the state on activities of companies and production process became important. At this point, these developments caused the birth of CSR in business world. The significance of CSR has increased from day to day (Post, Frederick, Lawrence \& Weber, 1996).

Political Factors: After the Second World War, states went into division as the Western Bloc which are made up the United States of America (USA), its North Atlantic Treaty Organization (NATO) allies and others and the Eastern Bloc which consists of the Soviet Union. On the other hand, many states entered into the process of democratization in the twentieth century. Besides civil liberties progressed in favor of individuals within these years. As the importance of individual rose, businesses had a high opinion of individuals and society. In the light of these developments, CSR activities of companies have increased dramatically (Aktan \& Börü, 2007).

Social Factors: There is no doubt that interactive relation and communication of societies developed in the 1900s. Correspondingly, individuals began to act in concert within society. When 1930s comes employees obtained union rights and demanded better employment opportunities and living conditions. Social ethics substituted for individualism and utilitarianism. All these social upheavals induced the reorientation of companies on their stakeholders. As a consequence of these changes, especially multinational corporations started to build good relationships with all stakeholders in order to gain competitive and sustainable advantage against rivals (Ataman, 2001; Güngör, 2010). In this regard, the notion of CSR became more important in today's modern business world.

\section{Four dimensions of CSR}

The concept of CSR must be concretized and explained its dimensions with regard to fulfilment social responsibilities of companies. According to Carroll (1979, 1991), CSR is composed of four basic dimensions (Figure 1). Within this scope, it includes economic responsibilities, legal responsibilities, ethical responsibilities and philanthropic responsibilities (Carroll, 1979, 1991; Daft, 2000; Ferrell, Fraedrich \& Ferrell, 2005). These responsibilities aim to contribute all stakeholders of the company (Carroll, 1991).

Friedman (1970) believes that the main objective of companies is to maximize profits so that they could survive. Therefore, economic responsibilities result from the aim of making 
profit. Economic responsibilities underpin CSR pyramid and other responsibilities are based on the presence of economic responsibilities. While society accepts the reality of maximum profit, it underlines companies take in consideration legal restrictions. It is expected that firms carry on their activities within the limits of the law as a 'social contract' between the community and companies (Carroll, 1991). Legal responsibilities of businesses require law-abidingness.

Even though economic and legal responsibilities of firms involve some ethical norms such as fairness or justice, ethical responsibilities comprise activities and practises which are expected or prohibited by society. According to Carroll (1991), ethical responsibilities contain standards, norms and expectations which reflect perception of consumers, employees, shareholders and society on fairness and justice. Philanthropy embodies company activities which are carried out in return for community's expectation that firms be good corporate citizens. In one sense, philanthropy involves engaging in activities and programs in order to support human welfare (Carroll, 1991). For example, company allocates its resources for the arts, culture, education or society in terms of social responsibility activities.

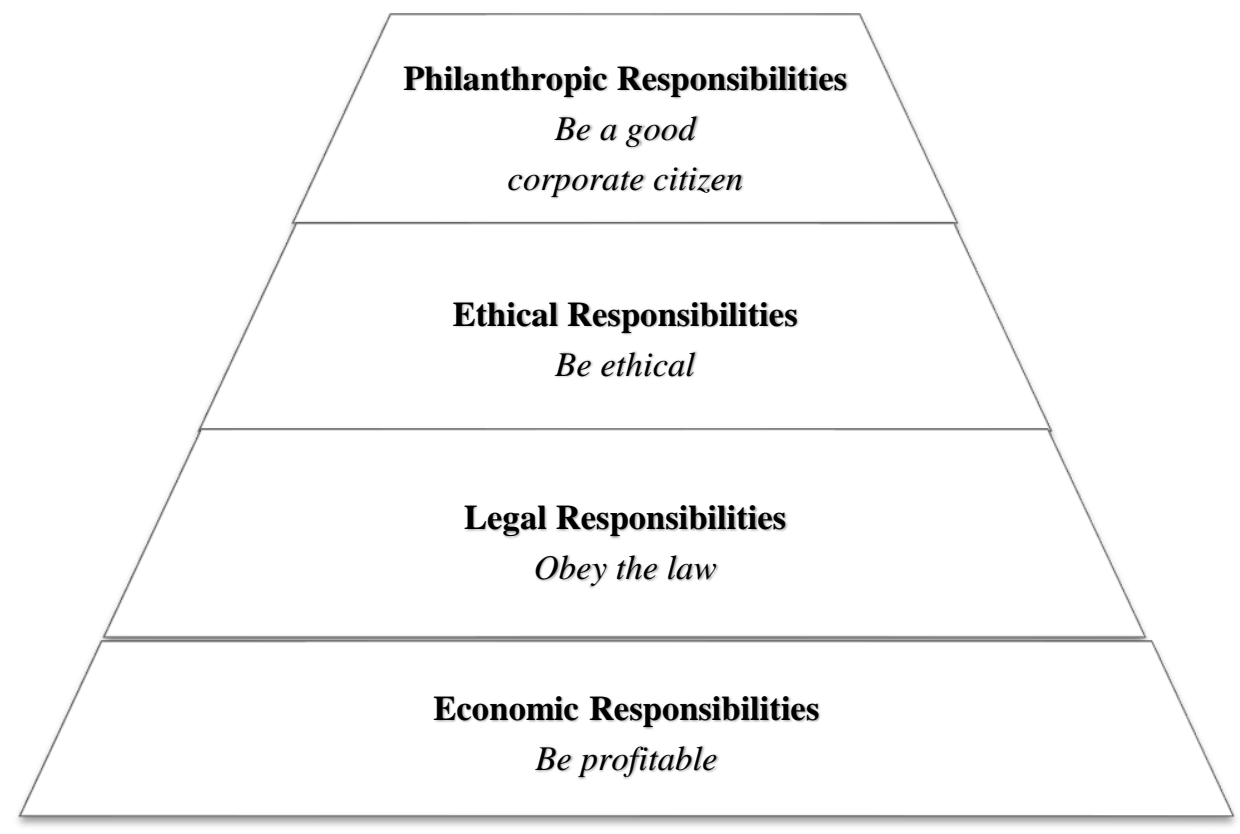

Figure 1: Carroll's (1979) pyramid of CSR

\section{Theoretical Framework}

Since 1960s CSR has been debating theoretically in the academic literature. Relevant to this matter, there are two main approaches on social responsibilities of companies. Some researchers think that companies have only one responsibility which is to maximize shareholder wealth in legal requirements (Carr, 1968; Friedman, 1970; Lewitt, 1958). On the other side, some scholars believe that businesses have extensive social responsibilities towards the community. Hence businesses should serve various stakeholders rather than shareholders (Donaldson \& Preston, 1995; Freeman, 1984; Jones, 1995). In this context, shareholder theory and stakeholder theory comprise the theoretical basis for this study. Aside from these theories, institutional theory has been extensively used in academic studies. Consequently, shareholder theory, stakeholder theory and institutional theory will be investigated within theoretical framework of the study.

\section{Shareholder theory}

Fundamentally, shareholder theory is related to the maximization of shareholder value and returns (Carr, 1968; Friedman, 1970; Lewitt, 1958). In compliance with shareholder 
approach, social responsibility activities give rise to abuse of business resources since these resources should be returned to shareholders. Concerning this issue, Friedman (1970) alleges that if the implementation of social demands enhances shareholder wealth, it should be done. Nonetheless, if the community's expectations solely inconvenience company in terms of costs, they shoud be refused.

Even though they are not in accordance with the Friedman's view, some researchers are still following of shareholder theory. To give an example, Porter and Kramer (2002) debate that firms should give up some activities which neither profit is made nor added value is created. On the other hand, Porter and Kramer (2002) indicate that if philanthropic or charitable activities are maintained continuously, those social activities will maximize the value created.

In today's business world, shareholder wealth maximization could be accomplished coupled with other stakeholders' contentedness (Garriga \& Melé, 2004). In addition to this opinion, Jensen (2002) claims that shareholder value maximization should be merely goal of business. That goal should be at the center of the decision criterion and tradeoffs should be made between conflicting demands of different stakeholders (Jensen, 2002).

\section{Stakeholder theory}

In opposition to shareholder theory, stakeholder theory which is the most widely accepted approach in the CSR literature promotes manager's support of CSR (McWilliams \& Siegel, 2001). The term "stakeholder" was used for the first time by Stanford Research Institute's work in 1963. In this study, stakeholders are described as "those groups without whose support the organization would cease to exist" (Freeman, 1983). During the 1980s, stakeholder approach was advanced by R. Edward Freeman in terms of its definition and importance. Freeman (1984) defines the notion of stakeholder as "any group or individual who can affect or is affected by the achievement of the organization's objectives" in his pioneering study. In addition to this, Freeman (1984) explains that managers should conduct processes so as to gratify all stakeholders. At this point, the management of various stakeholder groups' interests is crucial with regard to company's long-term success.

On the other hand, Donaldson and Preston (1995) seperate stakeholder theory as descriptive, instrumental and normative to clarify this approach. Stakeholder theory is descriptive approach since it accepts that businesses have different stakeholders. Besides stakeholder theory is instrumental as management of stakeholders increases company performance (Bilgehan, 2012). At the same time, stakeholder theory has a normative base although it is descriptive and instrumental (Donaldson \& Preston, 1995). According to the normative base, stakeholders have valid interests and each interest merits consideration for its own sake. Within this context, stakeholder approach encourages behaviors, manners, practices and structures in order to create an effective stakeholder management which considers interests of all stakeholders. As it is understood from academic studies, stakeholder theory has the aim of describe the groups. Herein, firms are responsible and consequentially constitute a source by prioritizing and legitimizing these groups' influence in corporate decision making process (Matten, Crane \& Chapple, 2003).

\section{Institutional theory}

Propensity to social responsibility activities differs between companies and countries. Thus, even more research is required in order to find out reasons behind this reality (Campbell, 2007). Matten and Moon (2008) emphasize that these international differences could be hitched on to diversity of rooted institutions. Within this scope, institutional theory provides the discovery of all stakeholders' motives in their cultural, national and institutional contexts (Matten \& Moon, 2008). 
Institutions such as states, governments, supranational organizations and NGOs exert influence on businesses by compelling them respond to these influences (DiMaggio \& Powell, 1983; Oliver, 1991). Some researchers (DiMaggio \& Powell, 1983; Meyer \& Rowan, 1977; Oliver, 1991; Zucker, 1977) believe that adapting and responding to institutional pressures enhances organization's chance of survival since it enables stability, prestige, legitimacy, qualified staff and access to resources. In this respect, organizations adapt pressures which are normative, coercive and mimetic from external environment and therefore they become isomorphic with their environments (DiMaggio \& Powell, 1983; Meyer \& Rowan, 1977).

Normative pressures consist of standards, norms and values shaped by various organizations like educational organizations, trade associations, industry groups, NGOs, etc. Normative pressures create alteration in organizational structures, processes and practises (Bilgehan, 2012). In this sense, growing adoption of schemes such as UNGC, OECD Guidelines for Multinational Enterprises, announcement of CSR activities within company's annual reports and increasing CSR related courses and programs in universities can be pass for a response to normative pressures (Sakarya et al., 2012).

Second, coercive pressures result from formal and informal pressures imposed on organizations in the shape of force, invitation or persuasion by institutions (DiMaggio \& Powell, 1983). States and governmental institutions are main actors which directly make laws and impose procedures. Businesses have to respect laws and procedures to survive in their environment. To exemplify, European Union (EU) provides expansion of CSR activities in between member states. In opposition to pressure in the shape of force, EU might indirectly exert pressure on the non-EU members with related standards such as ISO 14001, SA8000 or AA1000 (European Commission, 2004).

Third and lastly, mimetic pressures accompany normative and coercive pressures. DiMaggio and Powell (1983) highlight that firms tend to mimic other prospering businesses when external environment is uncertain. They try to understand social responsibility activities of competitors and gain competitive advantage. For this reason, domestic companies imitate CSR activities of multinational corporations (MNCs) and other successful businesses. In addition, MNCs mimic prevalent CSR practises in host country to improve their legitimacy.

\section{Methodology}

The previous chapter which is literature review demonstrated the conceptual and theoretical framework of CSR to create the infrastructure of this study. It is significant to consider the fact that presenting and justifying an effective research approach enhances its validity (Cresswell, 2007). Research is about carrying out an acceptable investigation so as to find answers or solutions to proposed research questions. Leedy (1989) believes that making a decision regarding an appropriate research methodology is therefore a fundamental part of outlining the steps to be taken to complete it. Blaikie (2000) explains that methodology "refers to decisions of how research is done, or should be done, and to the critical analysis of methods of research" (p. 8).

\section{Research Objectives}

Research objectives are formed by making specific lists of the various tasks in order to achieve goals of any project. These objectives help the researcher when he or she analyses whether the aims will be accomplished and achieved. The purposes of this study are that to examine scope and importance of CSR in today's business world, to reveal CSR practises of national, foreign and private banks listed in BIST 30 Index in Turkey and to analyse the differences between these banks in terms of fulfilment of their social responsibilities. In parallel with the main aim of the study, research question which is "What are the differences between 
national banks, foreign banks and private banks in Turkey in terms of the fulfilment of their social responsibilities?" will be answered.

\section{Research Design and Strategy}

When designing research, the most important factor is that determining researh type of the study. At this juncture, research methods are divided into two broad types of research strategy as quantitative and qualitative research (Blaikie, 2000; Bryman, 1988, 2012; Bryman $\&$ Bell, 2007; Saunders et al., 2009). Yet, the preference between quantitative and qualitative methods depends on different considerations such as research approach, research strategy, research philosophy or researcher's nature since the preference of research strategy, design and method are guided by research objectives and research questions of the study. Hence the choice of researcher is determined by the need to meet desired objectives (Blaikie, 2000; Bryman \& Bell, 2007; Saunders et al., 2009).

As indicated earlier, the main aims of this research investigating CSR practises of national, foreign and private banks listed in BIST 30 Index in Turkey and revealing the differences between these banks in terms of fulfilment of their social responsibilities. Hence, qualitative research was considered to be useful method so as to clarify the differences in social responsibility practises. In this context, in line with Bryman and Bell (2007), this study applies content analysis as a qualitative research method which entitles the researcher to view social reality more subjectively.

\section{Content Analysis}

Content analysis is used to specify the existence of concepts and certain words in texts or sets of texts. Researchers and scholars quantify the existence, meanings or relationships of concepts and words. Content analysis method is commonly used in many similar CSR studies (Abbott \& Monsen, 1979; Anderson \& Frankle, 1980; Bowman \& Haire, 1975; Ertuna \& Tükel, 2009, 2010; Gray, Kouhy, \& Lavers, 1995; Ingram, 1978). Within these studies; some factors such as number of pages, sentences or words are counted in order to quantify reported CSR activities of companies. In the present study, content analysis was carried out so as to investigate CSR declarations of companies. Within this context; relevant corporate governance compliance reports, sustainability reports or annual social responsibility reports were evaluated in content analysis.

\section{Sample}

This study carries out a comparative analysis on CSR practises of banks which are included in BIST 30 Index as of the second quarter of year 2016 (April - June). The list was obtained from the official website of BIST. The reason why choosing BIST 30 Index as a sample is the availability of sufficient data concerning CSR activities of banks. Furthermore, except for these banks' voluntary disclosures of their CSR activities, the obligation to publish corporate governance compliance reports for the listed companies in BIST 30 Index increases the availability of archival data. Additionally, the most successful companies are listed every year in different stock indices such as BIST 30, BIST 50 or BIST 100 in Turkey.

As the name of BIST 30 suggests, this index consists of 30 companies. These companies are seperated into 12 different groups according to their branch of industry (Borsa İstanbul, 2016). Within this scope; there are 6 companies in banking industry, 4 companies in automotive industry, 4 companies as holding structure, 3 companies in iron steel industry, 3 companies in transportation industry, 2 companies in food industry, 2 companies in petrochemical industry, 2 companies in telecommunication industry, 1 company in construction industry, 1 company in 
durable good industry, 1 company in real estate investment and 1 company in retail trade industry (Table 1).

Table 1: Distribution by sectors of companies

\begin{tabular}{|l|l|l|}
\hline Sectors & Number & Percentage (\%) \\
\hline Banking & 6 & 20 \\
\hline Automotive & 4 & 13,33 \\
\hline Holding & 4 & 13,33 \\
\hline Iron Steel & 3 & 10 \\
\hline Transportation & 3 & 10 \\
\hline Food & 2 & 6,67 \\
\hline Petrochemical & 2 & 6,67 \\
\hline Telecommunication & 2 & 6,67 \\
\hline Construction & 1 & 3,33 \\
\hline Durable Good & 1 & 3,33 \\
\hline Real Estate Investment & 1 & 3,33 \\
\hline Retail Trade & 1 & 3,33 \\
\hline
\end{tabular}

As it is seen from Table 1, majority of businesses carry on their activities in banking industry (Borsa İstanbul, 2016). For this reason, CSR practises of banks were investigated and compared in the study. Regarding banking industry; three of those are private banks, two of these are national banks and there is one foreign bank in BIST 30 Index (Table 2). Yet, one private bank (T. Is Bankasi A.S.), one national bank (Türkiye Vakiflar Bankasi T.A.O.) and one foreign bank (T. Garanti Bankasi A.S.) were selected among these six banks in order to compare their social responsibility practises. Consequently, CSR activities of three different banks were analyzed and contrasted in this study.

Table 2: All banks in BIST 30 index

\begin{tabular}{|l|l|}
\hline Bank Name & Type of Bank \\
\hline Akbank T.A.S. & Private \\
\hline T. Garanti Bankasi A.S. & Foreign Ownership \\
\hline T. Halk Bankasi A.S. & National \\
\hline T. Is Bankasi A.S. & Private \\
\hline Türkiye Vakiflar Bankasi T.A.O. & National \\
\hline Yapi ve Kredi Bankasi A.S. & Private \\
\hline
\end{tabular}

\section{Data Collection}

Relevant data were acquired from archival sources which are made up corporate governance compliance reports, annual sustainability reports and official websites of banks. Moreover, various resources were used so as to collect data concerning CSR activities of banks. In this regard, corporate governance compliance reports and social responsibility chapters of annual reports and were constituted the main sources of information. Besides, all information with regard to CSR on the website of banks and available CSR or sustainability reports of banks were also useful.

\section{Findings and Results}

Every words, sentences, concepts or projects which are related to CSR were evaluated and coded as a social responsibility activity. These CSR practises of banks were categorized under five headings as environmental conservation, health and safety, education, cultural/arts/sports, and stakeholders (Table 3).

Concerning environmental conservation activities of banks some relevant words such as environment, air, water, refining, energy, efficiency, emission, clean, fresh, waste, biodiversity, green, forest, tree, saving, conservation, ozone, etc. were counted and coded as a CSR 
activity. As can be seen from the Table 3, Isbank carries out 514 social responsibility activities on environmental conservation. Similarly, VakıfBank implements 584 CSR practises. On the other hand, Garanti Bank fulfills 1019 environmental conservation activities.

In regard to health and safety activities of banks some relevant words including health, work safety, quality, product, welfare, happiness, donation, accident, child, disabled, family, disease, blood, vaccine, etc. were counted and coded as a CSR activity. From the Table 3 it is clear that Isbank fulfills 144 activities, VakıfBank carries out 207 practises and Garanti Bank implements 296 CSR activities about health and safety.

In the sense of banks' education activities some relevant words like education, school, library, book, scholarship, training support, incentive, campaign, career, university, college, high school, primary school, sponsor, etc. were counted and coded as a CSR activity. As is shown by the Table 3, Isbank implements 282 social responsibility activities, VakıfBank fulfills 153 practises and Garanti Bank carries out 134 CSR activities on education.

In terms of cultural/arts/sports practises of banks some relevant words such as culture, art, sports, festival, theatre, movie, concert, music, painting, exhibition, photograph, football, basketball, volleyball, tennis, swimming, etc. were counted and coded as a CSR activity. It can be seen from the Table 3, Isbank carries out 251 CSR activities and VakıfBank implements 323 social responsibility practises. However, Garanti Bank only fulfills 121 cultural/arts/sports activities.

Regarding stakeholder-oriented practises of banks some relevant words including society, community, employee, employer, personnel, staff, manager, customer, shareholder, owner, supplier, competitor, partner, government, etc. were counted and coded as a CSR activity. Table 3 indicates numerically CSR practises of banks in the area of stakeholders. As is illustrated by the graph, Isbank fulfills 319 practises, VakıfBank carries out 361 activities and Garanti Bank implements 406 stakeholder-oriented activities.

Table 3: Subject Areas of CSR Practises

\begin{tabular}{|l|l|l|l|}
\hline Subject Area & Isbank & VakıfBank & Garanti Bank \\
\hline Environmental Conservation & 514 & 584 & 1019 \\
\hline Health and Safety & 144 & 207 & 296 \\
\hline Education & 282 & 153 & 134 \\
\hline Cultural/Arts/Sports & 251 & 323 & 121 \\
\hline Stakeholders & 319 & 361 & 406 \\
\hline
\end{tabular}

Table 4 depicts statistically social responsibility activities of banks according to specified CSR categories. All in all, banks carried out 2117 CSR practises about environmental conservation. They also implemented 647 social responsibility activities on health and safety. These banks fulfilled totally 569 education activities. Banks performed 695 CSR activities which are related to cultural/arts/sports. In addition to these, they carried out 1086 stakeholderoriented practises.

Table 4: Statistics of CSR Categories

\begin{tabular}{|l|l|}
\hline CSR Categories & Total Activity \\
\hline Environmental Conservation & 2117 \\
\hline Health and Safety & 647 \\
\hline Education & 569 \\
\hline Cultural/Arts/Sports & 695 \\
\hline Stakeholders & 1086 \\
\hline Total & 5114 \\
\hline
\end{tabular}


Table 5 gives a general review about banks' social responsibility activities. According to all archival sources of banks, Isbank implemented totally 1510 CSR activities. Whilst VakıfBank carried out 1628 practises, Garanti Bank fulfilled 1976 social responsibility activities.

Table 5: Results of Banks' CSR Activities

\begin{tabular}{|l|l|}
\hline Bank Name & Total Activity \\
\hline Isbank & 1510 \\
\hline VakıfBank & 1628 \\
\hline Garanti Bank & 1976 \\
\hline
\end{tabular}

Discussion

\section{Environmental Conservation}

The present study revealed that a great majority of CSR activities are carried out about environmental conservation. According to the study results, environmental conservation activities play an important role on CSR activities of Isbank, VakıfBank and Garanti Bank. All banks attach great importance to the environment conservation practises and projects. Within this scope, various theories including shareholder theory, stakeholder theory and institutional theory which were explained in literature review part of the study influence banks' attitudes.

From the point of Isbank, shareholder theory can be the reason behind it. Because the vision of Isbank is to be the most preferred bank for shareholders, customers and employees by sustaining its leading, pioneering and trusted position as a regional financial power. The top management of Isbank believe that the sustainability policy ensures energy efficiency, economic profitability and reduces resource consumption to support sustainable development is an element which will gradually become more important in the future strategies of Turkey (Isbank, 2016).

In the sense of VakıfBank, the Bank promotes sustainable development that consists of environmental, social and economic dimensions to create a better world and future. In line with its foundation culture, it serves to sustainable development through its services and products supplying individuals expectations and needs, improving the welfare, improving the social justice and aiming at environmental protection (VakıfBank, 2016). Taking into account all of these, it can be said that VakıfBank cares environmental conservation activities with reference to stakeholder theory.

Similarly, as part of stakeholder theory, Garanti Bank maintains sustainable economic growth by creating value to all stakeholders. Garanti Bank strengthens its sustainable banking approach by way of social responsibility activities including environmental conservation. The Bank's policy which is related to the environment is based upon some principles: to follow and abide exactly by environmental requirements and legislation, to follow and examine attentively sustainability programs about environmental conservation, climb over the mere fulfilment of necessities under the programs joined, to respect the environment, adopt and propagate environmental responsiveness, to provide and encourage the efficient usage of all resources (Garanti Bank, 2016).

\section{Health and Safety}

It is observed that health and safety activities of banks are lower level in comparison to environmental conservation activities (Table 3). Although banks disclose different projects and practises on health and safety, they give little importance to this area. The occupational accident rate of Turkey is higher than the world average. In the light of this fact, it was expected that banks will implement more health and safety practises and projects in Turkey. However, the study results revealed that all banks emphasise environmental conservation and stakeholder- 
oriented activities rather than health and safety practises (Table 3). This can be attributed to the community's expectations from the banks. Regarding this issue the survey of Capital (2012), which is one of the leading business magazines in Turkey, demonstrates that the community needs businesses which pay attention to the environmental conservation and human rights areas. For this reason, it can be said that all banks prefer to fulfill environmental conservation and stakeholder-oriented practises but rather health and safety activities.

\section{Education}

In common with health and safety practises, from the Table 3 it is clear that education activities of banks are lower than environmental conservation and stakeholder-oriented activities. Even though banks have various practises and projects such as "81 Students from 81 Cities" Project and "One Million Books, One Million Children" Campaign (Isbank, 2016), "Hand In Hand With ZICEV" (VakıfBank, 2016), "The Teachers' Academy Foundation" (Garanti Bank, 2016); all of them underemphasize social responsibility activities about education.

If the inequality in the number of CSR practises is taken into consideration, it is seen that Isbank, as a private bank, pays much more attention to projects and practises on the education compared to VakifBank (national bank) and Garanti Bank (foreign bank). Unlike the example of governmental pressures on companies with regard to environmental conservation, there is not coercive and normative pressure from Ministry of National Education or other institutions about social responsibility activities of companies in Turkey. At this point, it can be said that banks undervalue education projects and activities contrary to expectations.

\section{Cultural/Arts/Sports}

Concerning cultural/arts/sports, all banks have different practises like "Is Sanat Concert Hall", "Is Sanat Art Galleries", "Isbank Museum", "Istanbul Foundation for Culture and Arts The Istanbul Music Festival", etc. (Isbank, 2016), "VakıfBank Sports School”, "World Heritage Istanbul", "Bridge Group Exhibition", etc. (VakıfBank, 2016), "Salt Beyoğlu", "Salt Galata", "Salt Ulus" and "Garanti Children's Film Festival" (Garanti Bank, 2016). These cultural/arts/sports practises of banks can be linked with the society's expectations and the philanthropic responsibilities of Carroll's CSR Pyramid.

According to Carroll (1991), philanthropy embodies company activities which are carried out in return for the community's expectation that firms be good and responsible corporate citizens. In one sense, philanthropy approach involves engaging in activities and programs in order to support human welfare. For example, company allocates its resources for the arts, culture, sports or society with regard to social responsibility practises (Carroll, 1991). Turkey has a remarkable philanthropic history and many organizations still continue the tradition so as to carry out community's expectations via philanthropic activities. Therefore, it can be said that banks behave in conformity with the community's philanthropic expectations and promote cultural/arts/sports activities.

\section{Stakeholders}

This study revealed that following environmental conservation activities a major part of social responsibility practises are carried out about stakeholders. As it is seen from the Table 3, all banks pay special attention stakeholder-oriented activities. Despite the fact that shareholder theory and institutional theory play an important role on CSR activities of banks, stakeholder theory fundamentally influences attitudes of banks with regard to stakeholder-oriented social responsibility activities. 
Isbank pays regard to continuous communication with its stakeholders so as to be an important element in developing the required policies and structuring operations. Stakeholder communication is a two-way, transparent process overlapping with the Bank's goal to create a long-term contribution for the society. Thus, Isbank exchanges opinions with stakeholders through various communication channels. Isbank considers different opinions and input received from stakeholder communication during the process of developing social responsibility projects (Isbank, 2016).

VakıfBank defines all people, institutions and organizations that are affected by its products and services and can play an active role in achieving the Bank's strategic objectives as stakeholders. VakıfBank develops its sustainability strategy and social responsibility activities in line with the views and expectations of stakeholders and regularly communicates with them through various channels. Moreover, VakıfBank is constantly working to create value by getting quickly into action in line with the feedback of the key stakeholders located in the centre of the sustainability strategy (VakıfBank, 2016).

Garanti Bank takes advantage of the feedback in order to identify strategically important problems with its stakeholders and also to center upon the most relevant sustainability subjects for the Bank and its stakeholders. In addition to this, it had an interview countless strategic customers so as to determine their expectations and needs from Garanti Bank and the banking sector. Based on its customers feedback, Garanti Bank brought up to date sustainability strategy to educate its customers on the notion sustainability (Garanti Bank, 2016).

\section{Conclusions, Limitations and Recommendations}

The present study revealed that more than $40 \%$ of CSR activities are carried out in environmental conservation and all banks primarily emphasize this area. As stated previously; shareholder theory, stakeholder theory and institutional theory play a significant role on environmental conservation practises of banks. Furthermore, traditional philanthropy approach and the society's expectations from banks may be the reason behind it. Following environmental conservation activities, a major part of social responsibility practises are implemented about stakeholders. As it is seen from the Table 4, all banks pay special attention stakeholder-oriented activities. This can be attributed to stakeholder theory.

On the other hand, Table 5 gives a general assessment about banks' social responsibility activities. It is observed that Isbank implemented 1510 CSR activities, VakıfBank carried out 1628 practises and Garanti Bank fulfilled 1976 social responsibility activities in total. According to the study results, there are not important differences between Isbank and VakıfBank regarding the fulfilment of their social responsibilities. Garanti Bank implemented more CSR practises and therefore it reached more people in comparison with other banks. This may be attributed to philanthropy approach and local limitations in Turkish business environment.

Due to the traditional and religious factors, philanthropy has been a quite dominant behavior in Turkey. Even though there is a transition from philanthropic activities to CSR practises, some Turkish businesses still continue this tradition. Companies either implement philanthropic activities and CSR practises at the same time or they limit their activities to philanthropic ones (Bilgehan, 2012). Local community development stays as a priority on their agenda. Hence, social responsibility activities of Turkish banks are restricted to local borders. From this point of view, it can be said that Garanti Bank attached particular importance to social responsibility activities as it is a foreign bank.

This study has a number of shortcomings. First of all, the sample was made use of BIST 30 Index in this study. As majority of companies carry on their activities in banking industry 
(Table 1), CSR practises of banks were examined within the study. In this context; one private bank (Isbank), one national bank (VakıfBank) and one foreign bank (Garanti Bank) were selected from six banks within BIST 30 Index so as to analyze and compare their social responsibility activities. For this reason, the sample of research was composed of only three banks. Second, conclusions of this study were drawn based on the data for the second quarter of year 2016 (April - June). There are four index periods for BIST 30 Index which consist of January-March, April-June, July-September and October-December (Borsa İstanbul, 2016). This study solely focused on CSR activities of banks which are included in BIST 30 Index as of the second quarter of year 2016.

Recommendations for future studies aim to contribute researchers and future studies. From this point of view, a number of recommendations can be given. First of all, a similar study of this thesis can be done using different samples or populations. This study analyzed and compared CSR practises of banks in BIST 30 Index. Therefore, the sample of research consists of only three banks. In the future, CSR activities of other firms which are operating in different industries within BIST 30 Index could be analyzed. Second, conclusions of the study were drawn based on the data for the second quarter of year 2016 (April - June). This study solely focused on CSR activities of banks which are included in BIST 30 Index as of the second quarter of year 2016. However, social responsibility activities of banks can be analyzed for other periods and years so as to reveal the exact CSR practises of banks.

\section{Acknowledgement}

This paper is based on a Master's thesis titled " A Comparative Analysis of Corporate Social Responsibility Activities of Companies in Banking Industry: An Application From Turkey" completed at Swansea University School of Management under the supervision of Ms. Sarah Peasley in 2016.

\section{References}

Abbott, W. F. \& Monsen, R. J. (1979). On the measurement of corporate social responsibility: Self-reported disclosures as a method of measuring corporate social involvement. Academy of Management Journal, 22(3), 501-515.

Aktan, C. C. \& Börü, D. (2007). Kurumsal sosyal sorumluluk. İstanbul: İgiad.

Anderson, J. C. \& Frankle, A. W. (1980). Voluntary social reporting: An iso-beta portfolio analysis. The Accounting Review, 55, 467-479.

Ataman, G. (2001). Işletme yönetimi: Temel kavramlar ve yeni yaklaşımlar. İstanbul: Türkmen.

Basu, K. \& Palazzo, G. (2008). Corporate social responsibility: A process model of sensemaking. Academy of Management Review, 33(1), 122-136.

Bilgehan, M. (2012). A comparative analysis of corporate social responsibility practices of Turkish companies and companies with foreign ownership (Unpublished Master's Thesis). Bogazici University, İstanbul.

Blaikie, N. (2000). Designing social research: The logic of anticipation. Cambridge: Polity Press.

Borsa İstanbul (2016). http://www.borsaistanbul.com/en/indices/bist-stock-indices

Borsa İstanbul (2016). http://www.borsaistanbul.com/docs/default-source/endeksler/biststock-indices-ground rules.pdf?sfvrsn $=12$

Bowen, H. R. (1953). Social responsibilities of the businessman. New York: Harper \& Row.

Bowman, E. H. \& Haire, M. (1975). A strategic posture toward corporate social responsibility. California Management Review, 18(2), 49-58.

Bryman, A. (1988). Quantity and quality in social research, London: Unwin Hyman.

Bryman, A. \& Bell, E. (2007). Business research methods, New York: Oxford University Press. 
Campbell, J. L. (2007). Why would corporations behave in social responsible ways? An institutional theory of corporate social responsibility. Academy of Management Review, 32, 946-967.

Carr, A. Z. (1968). Is business bluffing ethical? Harvard Business Review, 46(1), 143-153.

Carroll, A. B. (1979). A three-dimensional conceptual model of corporate performance. Academy of Management Review, 4(4), 497-505.

Carroll, A. B. (1991). The pyramid of corporate social responsibility: Toward the moral management of organizational stakeholders. Business Horizons, 34(4), 39-48.

Carroll, A. B. (1999). Corporate social responsibility. Business \& Society, 38(3), 268.

Carroll, A. B. \& Buchholtz A. K. (2000). Business and society: Ethics and stakeholder management. Cincinnati: South Western College Publishing.

Cresswell, J. W. (2007). Qualitative inquiry and research design: Choosing among five approaches. Thousand Oaks, CA: Sage Publications.

Daft, R. L. (2000). Management. New York: The Dryden Press.

Davis, K. (1960). Can business afford to ignore social responsibilities? California Management Review, 2(3), 70-76.

Davis, K. (1973). The case for and against business assumption of social responsibilities. Academy of Management Journal, 16(2), 312-322.

Davis, K. (1976). Social responsibility is inevitable. California Management Review, 19(1), 1420.

DiMaggio, P. J. \& Powell, W. W. (1983). The iron cage revisited: Institutional isomorphism and collective rationality in organizational fields. American Sociological Review, 48(2), 147-160.

Donaldson, T. \& Preston, L. E. (1995). The stakeholder theory of the corporation: Concepts, evidence, and implications. Academy of Management Review, 20(1), 65-91.

Drucker, P. (1954). The practice of management. New York: Harper \& Row.

Erden, P. (2011). Çalışanların kurumsal sosyal sorumluluk algılarının örgütsel bağlılıkları üzerine etkisi: Karşılaştırmalı bir araştırma (Yayınlanmamış Yüksek Lisans Tezi). Gazi Üniversitesi, Ankara.

Ertuna, B. \& Tükel, A. (2009). CSR practises in Turkey: In between traditional and global. Journal of Management Research, 9(2), 145-172.

Ertuna, B. \& Tükel, A. (2010). Traditional versus international influences: CSR disclosures in Turkey. European Journal of International Management, 4(3), 273-289.

European

Commission

(2004).

http://ec.europa.eu/environment/gpp/pdf/buying_green_handbook_en.pdf

Ferrell, O. C., Fraedrich, J. \& Ferrell, L. (2005). Business ethics: Ethical decision making and cases, New York: Houghton Mifflin.

Frederick, C., Davis, W. \& Post, E. J. (1988). Business \& society: Corporate strategy, public policy, ethics. New York: McGraw-Hill Education.

Freeman, R. E. (1983). Stockholders and stakeholders: A new perspective on corporate governance. California Management Review, 25(3), 88-106.

Freeman, R. E. (1984). Strategic management: A stakeholder perspective. Englewood Cliffs, NJ: Prentice Hall.

Friedman, M. (1962). Capitalism and freedom. Chicago: University of Chicago Press.

Friedman, M. (1970). The social responsibility of business is to increase its profits. New York Times Magazine, September 1.

Garanti Bank (2016). http://www.garanti.com.tr/en/our_company/sustainability.page

Garanti

Bank

(2016). http://www.garanti.com.tr/en/our_company/sustainability/developments/reports.page? $\operatorname{gbid} 2=202122$ 
Garriga, E. \& Mele, D. (2004). Corporate social responsibility theories: Mapping the territory. Journal of Business Ethics, 53, 51-71.

Gray, R., Kouhy, R. \& Lavers, S. (1995). Constructing a research database of social and environmental reporting by UK companies. Accounting, Auditing \& Accountability Journal, 8(2), 78-101.

Gülmez, E. (2011). Kurumsal sosyal sorumluluk çalışmalarının kurum imajına etkisi üzerine bir araştırma (Yayınlanmamış Yüksek Lisans Tezi). Marmara Üniversitesi, İstanbul.

Güngör, C. R. (2010). Kurumsal sosyal sorumluluk kampanyalarının işletmeye olan katkıları (Yayınlanmamış Yüksek Lisans Tezi). İstanbul Üniversitesi, İstanbul.

Hopkins, M. (2003). The planetary bargain: Corporate social responsibility matters. London: Earthscan Publications.

Ingram, R. W. (1978). An investigation of the information content of (certain) social responsibility disclosures. Journal of Accounting Research, 16, 270-285.

Isbank

http://www.isbank.com.tr/EN/aboutisbank/sustainability/Pages/sustainability.asp

Isbank (2016). http://www.isbank.com.tr/EN/about-isbank/sustainability/ourreports/Pages/ourreports.aspx

Jensen, M. C. (2002). Value maximization, stakeholder theory, and the corporate objective function. Business Ethics Quarterly, 12(2), 235-256.

Jones, T. M. (1995). Instrumental stakeholder theory: A synthesis of ethics and economics. Academy of Management Review, 20(2), 404-437.

Kalkan, S. (2008). Quality of information produced by producers: Greenwashing or can we really trust? Consumer Citizenship, 4, 93-107.

Kotler, P. \& Lee, N. (2005). Corporate social responsibility. New Jersey: John Wiley \& Sons, Inc.

Lee, M. P. (2008). A review of the theories of corporate social responsibility: Its evolutionary path and road ahead. International Journal of Management Reviews, 10(1), 53-73.

Leedy, P. D. (1989). Practical research, New York: Macmillan.

Lewitt, T. (1958). The dangers of social responsibility. Harvard Business Review, 36(5), 4150 .

Matten, D., Crane, A. \& Chapple, W. (2003). Behind the mask: Revealing the true face of corporate citizenship. Journal of Business Ethics, 45(1), 109-120.

Matten, D. \& Moon, J. (2008). Implicit and explicit CSR: A conceptual framework for a comparative understanding of corporate social responsibility. Academy of Management Review, 33(2), 404-424.

McGuire, J. W. (1963). Business and society. New York: McGraw-Hill.

McWilliams, A. \& Siegel, D. S. (2001). Corporate social responsibility: A theory of firm perspective. Academy of Management Review, 26, 177-127.

Meyer, J. \& Rowan, B. (1977). Institutionalized organizations: Formal structure as myth and ceremony. American Journal of Sociology, 83(2), 340-363.

Oliver, C. (1991). Strategic responses to institutional processes. Academy of Management Review, 16(1), 145-179.

Porter, M. E. \& Kramer, M. R. (2002). The competitive advantage of corporate philanthropy. Harvard Business Review, 80(12), 56-68.

Sakarya, S., Bodur, M., Yildirim-Oktem, O. \& Selekler-Goksen, N. (2012). Social alliances: Business and social enterprise collaboration for social transformation. Journal of Business Research, 65(12), 1710-1720.

Saunders, M., Lewis, P. \& Thornhill, A. (2009). Research methods for business students. Essex: Prentice Hall.

VakıfBank (2016). https://www.vakifbank.com.tr/sustainability.aspx?pageID=1075 
VakıfBank (2016). https://www.vakifbank.com.tr/sustainability--reports.aspx?pageID=1318

Wood, D. J. (1991). Corporate social performance revisited. Academy of Management Review, $16,691-718$.

Yamak, S. (2007). Kurumsal sosyal sorumluluk kavramının gelişimi. İstanbul: Beta.

Zucker, L. G. (1977). The role of institutionalization in cultural persistence. American Sociological Review, 42(5), 726-743. 